SOIL SURVEY OF AREA 15

NEVADA TEST SITE

by

Verr D. Leavitt and Benjamin J. Mason

Radiological Research Program

Western Environmental Research Laboratory

ENV IRONMENTAL PROTECTION AGENCY

Published June 1971

THIS DOCUMENT CONFIRMED AS UNCLASSIFIED

DIVISION OF CLASSIFICATION

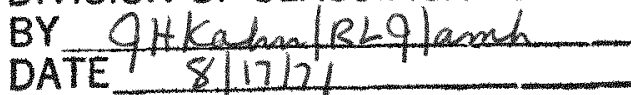

This study performed under a Memorandum of

Understanding (No. SF 54 373)

for the

U.S. ATOMIC ENERGY COMMISSION

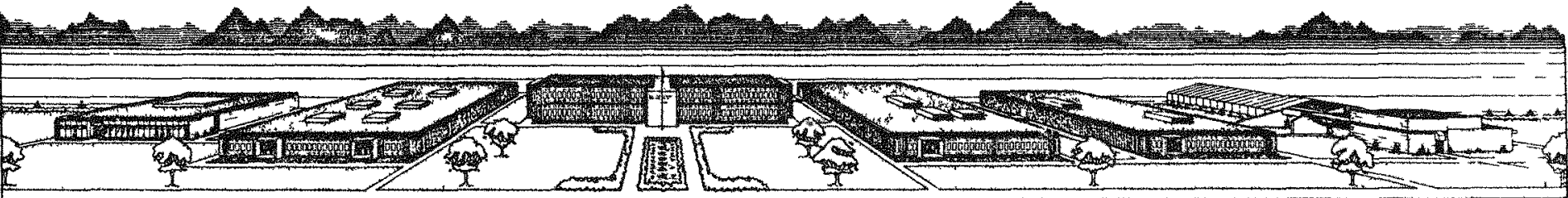


This report was prepared as an account of work sponsored by the United States Government. Neither the linited States nor the United States Atomic Enerqy Commission, nor any of their employees, nor any of their contractors, subcontractors, or their employees, makes anv warranty, express or implied, or assumes any legal liability or responsibility for the accuracy, completeness or usefulness of any information, apparatus, product or process disclosed, or represents that its use would not infringe privately-owned rights.

Available from the National Technical Information Service,

U. S. Department of Commerce, Springfield, VA. 22151

Price: paper copy $\$ 3.00$; microfiche $\$ .95$. 


\section{DISCLAIMER}

This report was prepared as an account of work sponsored by an agency of the United States Government. Neither the United States Government nor any agency Thereof, nor any of their employees, makes any warranty, express or implied, or assumes any legal liability or responsibility for the accuracy, completeness, or usefulness of any information, apparatus, product, or process disclosed, or represents that its use would not infringe privately owned rights. Reference herein to any specific commercial product, process, or service by trade name, trademark, manufacturer, or otherwise does not necessarily constitute or imply its endorsement, recommendation, or favoring by the United States Government or any agency thereof. The views and opinions of authors expressed herein do not necessarily state or reflect those of the United States Government or any agency thereof. 


\section{DISCLAIMER}

Portions of this document may be illegible in electronic image products. Images are produced from the best available original document. 


\title{
SOIL SURVEY OF AREA 15 NEVADA TEST SITE
}

\author{
by \\ Verr D. Leavitt and Benjamin J. Mason* \\ Radiological Research Program \\ Western Environmental Research Laboratory** \\ ENVIRONMENTAL PROTECTION AGENCY
}

Published June 1971

This report was prepared as an account of work
sponsored by the United States Government. Neither
the United States nor the United States Atomic Energy
Commission, nor any of their employees, nor any of
their contractors, subcontractors, or theur employees,
makes any warranty, express or implied, or assumes any
legal liability or responsibility for the accuracy, com.
pleteness or usefulness of any information, apparatus,
product or process disclosed, or represents that its use
would not infringe privately owned rights.

This study performed under a Memorandum of

Understanding (No. SF 54 373)

for the

U.S. ATOMIC ENERGY COMMISSION

* Dr. Benjamin J. Mason, Chief "Ecology Research Branch, EPA, Bureau of Air Pollution Sciences, Trianqle Park, N.C.

** Formerly Southwestern Radiological Health Laboratory, part of the U. S. Department of Health, Education, and Welfare, Public Health Service, Environmental Health Service, Environmental Control Administration, Bureau of Radiological Health. 


\section{ABSTRACT}

This report presents the results of a soil survey of the area around the Environmental Protection Agency Experimental Dairy Farm located in Area 15 of the U. S. Atomic Energy Commission's Nevada Test Site.

Four soil series were identified. Descriptions of these series are included along with physical and chemical analyses of representative samples of the soils. 
The authors would like to express their thanks to Dale D. Moden, Caroline S. Allen, Eleanor C, Strickland, Ralph F. Smiecinski, Ruby H. Fehler, and Wallace J. Wipper for their assistance in the chemical analysis of the soils collected during this survey. 


$\begin{array}{lc} & \text { Page } \\ \text { ABSTRACT } & \mathbf{i} \\ \text { ACKNOWLEDGMENTS } & i \text { i } \\ \text { LIST OF TABLE } & \text { iv } \\ \text { I. INTRODUCTION } & 1 \\ \text { II. DESCRIPTION OF STUDY AREA } & 2 \\ \text { A. Study Area } & 2 \\ \text { B. General Geology } & 2 \\ \text { C. Climate } & 3 \\ \text { D. Vegetation } & 5 \\ \text { E. Chemical Analysis } & 6 \\ \text { 1. Standard Soils Analysis } & 6 \\ 2 . \quad \text { Total Chemical Analysis } & 6 \\ \text { 3. Results } & 7 \\ \text { III. SOIL MAPPING PROCEDURES } & 8 \\ \text { BIBLIOGRAPHY } & 21 \\ \text { APPENDICES } & 22\end{array}$




\section{Page}

Table 1. Temperature and Precipitation Data 


\section{INTRODUCTION}

The Western Environmental Research Laboratory (WERL), Environmental Protection Agency (EPA), has maintained an experimental dairy farm on the U. S. Atomic Energy Commission's Nevada Test Site (NTS) since 1965. The crop area of the farm is maintained primarily for the production of forage to be used in experiments conducted by WERL. During controlled releases of radioactivity at this farm unexplained variations in the levels of retained activity have appeared. In order to provide information to aid in controlling this variation the soil survey presented in this report was conducted.

The actual soil survey was conducted in 1966 and the chemical analysis of samples collected during the survey has been underway since that time. Soil survey techniques patterned after the Soil Conservation Service's National Cooperative Soil Survey were used. 


\section{DESCRIPTION OF STUDY AREA}

A. Study Area.

The area surveyed lies in Township 8, South, Range 53 East, in Area 15 of NTS (see Appendix VI). The boundaries of the study area are Smoky Hills on the west, Oak Spring Butte on the north, Rhyolite Hills and Butte Wash on the east, and Sedan Crater on the south. The total area encompasses approximately 576 acres. The topography is generally gently-sloping alluvial fans. The study area occurs at an elevation of 4,500 feet. Much of the area especially to the north and east occurs on alluvial fans originating from the Quartzite Mountains and the Rhyolite Hills.

B. Geology.

Most of the soils in the area of this survey have been developed in sediments that were washed from the surrounding mountains and laid down by water. Locally, these sediments were reworked by wind. The remaining soils developed in residuum that weathered from rocks of the mouniains.

The sediments of the survey area were derived mainly from tuff, quartz, and limestone. A smaller amount of material came from dolomite, shale, and granite. The dolomite, shale, and quartzite were interbedded with massive beds of limestone.

The mountains surrounding the survey area consist mainly of tuffs with smaller areas of limestone, quartz, and other rock. The tuffs range in depth from surface outcrops to 1,000 feet below the surface. The tuffs occur in a variety of colors such as red, yellow, green, brown, gray, and black. 
C. Climate.

The WERL dairy farm has a semi-arid, continental climate.

Sunshine is abundant, precipitation is low, the rate of evaporation is high, and the air is dry and clear. In summer the days are hot but the nights are cool. Winters are fairly cold.

The location of the WERL dairy farm, being in a valley on a plateau between two major mountain ranges, accounts in large part for the semi-arid climate. To the west lie the Sierra Nevada, a massive range of mountains that effectively reduces the moisture content of storms moving inland from the Pacific Ocean during fall, winter, and spring. As moist air, in its easterly flow, is forced to rise over the mountains, it loses much of its moisture on the western slopes.

The air moving down the eastern slopes is warmed by compression and, when it reaches the interior valley, is relatively dry. As the air continues to move eastward each successive mountain range further reduces the moisture content and is a contributing reason for light precipitation in Area 15 of the NTS.

The average annual precipitation in this valley is about 5.71 inches. of the total yearly precipitation, about 40 percent comes in winter and early spring, and a large percentage falls during showers and thunderstorms in July and August. The most rainfall recorded in a monthly period is 3.69 inches, which fell in January 1969. The highest annual precipitation reported is 11.43 inches, and the lowest, 2.95 inches.

Snowfall in Area 15 is light, averaging about 12 inches annually. Its yearly total is rarely more than 2.5 feet, though the maximum annual snowfall may be as high as three feet. 
Table 1. Temperature and Precipitation Data.

Temperature data taken by ESSA at NTS (elevation 4,560 feet) for $3 \frac{1}{2}$ years, January 1966 to June 30, 1969. Rainfall measured at Area 15, WERL dairy

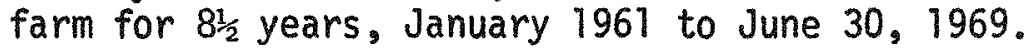

\section{Temperature}

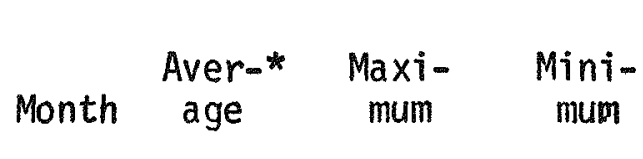

$\begin{array}{llll} & { }^{\circ} \mathrm{F} & { }^{\circ} \mathrm{F} & { }^{\circ} \mathrm{F} \\ \mathrm{Jan} & 40 & 64 & 16 \\ & 42 & 62\end{array}$

Feb $\quad 42 \quad 62 \quad 21$

Mar $\quad 48 \quad 74 \quad 22$

Apr $\quad 53 \quad 75 \quad 30$

May 63

Jun 69

JuT 75

Aug 73

Sept 70

Oct 60

Nov 49

Dec $\quad 40$

Total $\stackrel{\star}{*} 57$
90

95

96

96

90

81

74

63

80

\section{Rainfall}

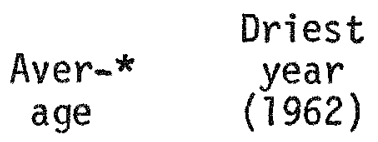

Wettest

year

(1965)

In

0.62

In

In

0.11

0.70

1.33

0.01

0.40

0.22

1.14

0.51

Trace

3.15

0.19

0.01

0.16

0.20

0.04

0.15

0.58

0.20

0.39

0.74

$+$

0.98

0.40

0.55

0.13

0.20

0.54

Trace

2.66

0.70

0.17

2.68

5.71

2.95

11.43

*Average for 12 months.

+Data unavailable.

* Total for 12 months. 
Thunderstorms occur on an average of about 20 days in a year. Heavy rains are of short duration, but at times more than one inch of rain falls during a heavy shower. Hail that accompanies a thunderstorm in summer does little damage because the hailstones are generally small. In the Area 15 valley the average daily range in temperature is great. It averages nearly $30^{\circ} \mathrm{F}$ in December and January, and $43^{\circ} \mathrm{F}$ in summer. The highest temperature observed during the period of record is $100^{\circ} \mathrm{F}$ and the lowest is $9^{\circ} \mathrm{F}$.

In the Area 15 valley the average growing season, or frost-free period, extends from the middle of May to the middle of October, a period of about five months. Frost has occurred, however, as late as June 1 and as early as September 20.

Table 1 gives the temperature and precipitation recorded at the WEP.L dairy farm by the ESSA. The temperature has been recorded for $3 \frac{1}{2}$ years and the precipitation for $8 \frac{1}{2}$ years. These records correspond very closely to the ones taken at Yucca Flat for the same period of time.

D. Vegetation.

The vegetation in Area 15 is typical of that found in semi-arid areas of the Southwest. Generaliy, it consists of good growth of desert shrubs and grasses.

The vegetation in Area 15 consists predominately of wolfberry (Lycium andersonii), small rabbitbrush (Chrysothamnus viscidiflomus), blackbrush (Coleogyne ramosissima), and Nevada joint-fir (Ephedra nevadensis). Other common species that occur are winter fat (Eurotia Zanata), desert needlegrass (Stipa speciosa), Indian ricegrass (orhyzopsis hymenoides), Joshua tree (Yucea brevifolia), bud sage (Artemisia spinescens), squirrel tail (Sitanion spp.), four-winged saltbush (Atriplex canescens), and a large number of species of buckwheat.

A good stand of desert shrub and grass vegetative cover is present on the soils. The survey area of Area 15 normally has a plant 
density of 10 to 25 percent. The vegetative cover contributes little organic matter to the soil, affords little protection against erosion, and provides little shade for the soil. High temperature, limited shade, and low organic matter content have resulted in an adverse habitat for 5011 microorganisms; thus, there is little microbial activity during much of the year.

E. Chemical Analyses.

Since one of the primary purposes of this survey was to provide data for use in the management of the WERL dairy farm, only those soils which occur on the growing areas were analyzed chemical7y.

Agricultural practices are considered to affect only the upper 6 to 10 inches of soil. The results presented in this report are from the analysis of the surface samples from the agricultural lands.

1. Standard Soils Analysis.

The methods used for the various analyses such as cation exchange capacity, $\mathrm{pH}$, exchangeable cations, conductivity, total nitrogen and phosphate were taken from Jackson's

Soil Chemical Analysis(1).

2. Total Chemical Analysis.

The method used for the elemental analys is of the farm soils is based on the preparation of standards by the addition of appropriate reagent grade chemicals to a soil that has a chemical matrix very similar to the average chemical matrix of the farm soils.

These standards were prepared by adding the reagent grade chemicals to five-gram samples of Carrizo soil (collected in Arizona near Mesquite, Nevada). The samples were then ground in a motorized mortar and pestle for fifteen minutes. 
Two grams of the ground soil aliquots were pelletized by the method of Volborth (2). An examination of the data shows obvious similarities and differences between the four soils. For example, they are similar in cation exchange capacity, exchangeable cations, conductivity, and ph. However, Thirsty soil is much lower in carbonates than the other soils. (There is also a very wide range in the molybdenum content of the four soils.)

The samples of farm soil were ground and pelletized in the same manner as the standards.

The samples were counted with a standard counter after every eighth sample. The percent of the element of interest was obtained by reading directly from the standard curve.

Although, not of a high degree of accuracy, this method fulfills the requirements for a study of this nature where the variation between duplicate field soil samples frequently has a range of \pm 10 percent of the mean. Comparisons between analysis by the $x$-ray method agree well with the wet chemistry methods.

3. Results.

The data are given in Appendix IX. The examination of the data of Appendix IX shows similarities and differences among the four soils. For example, they are similar in cation exchange capacity, exchangeable cations, conductivity, and $\mathrm{pH}$. Thirsty soils have less than half the carbonates of the other soils. They are similar in $\mathrm{Ca}, \mathrm{K}, \mathrm{Cl}, \mathrm{Mn}, \mathrm{Fe}, \mathrm{AT}, \mathrm{SiO}_{2}, \mathrm{Cu}$, $\mathrm{Zn}$, and $\mathrm{N}$.

There is some variation in $\mathrm{S}, \mathrm{Ti}, \mathrm{Mg}$, and phosphate. The widest variation is the molybdenum content with a range of $0.0 C 39$ to 0.0112 percent.

Note. If further information is desired it can be found in the Geologic Quadrangle - Geology of the Oak Spring Quadrangle - Nevada GQ214. 


\section{SOIL MAPPING PROCEDURES}

This soil survey was mapped according to the United States Department of Agriculture 1960 Soil Classification System and the 7 th Approximation System (see Appendix VI for map).

In general, this method involves digging soil pits or taking soil auger borings to enable the surveyor to determine the stratigraphy of the soil profile, the characteristics of the various layers, and to make field measurements on certain chemical and physical factors important to soil classification.

During the classification of the Area 15 soils eight pits were dug. Using the information gained from these pits four soil series were identified. The description of these series is presented below. At the same time the soil profiles were described, samples of each layer were taken for sphysical and chemical analyses.

The four soil series described in this survey are:

1. Banded

2. Butte

3. Twin Peaks

4. Thirsty

Although these soils are given classification names, they should not be considered as final, since this survey has not been correlated with the U.S. National Cooperative Soil Survey.

The terminology of the descriptions is defined in the mapping legend and in the Glossary which appear in Appendix VII and Appendix $X$, respectively. 
1. Banded: The Banded series comprises Typic Durorthids, members of sandy, mixed, calcareous, mesic family. Characteristically, the soils have pale brown moderately alkaline $A$ horizons of gravelly sandy loam and very pale brown strongly alkaline $C$ horizons grade into silica Cca horizons that range from soft to very hard and have a high content of silica and calcium carbonates (Cca).

Typifying Profile: Banded gravelly sandy loam (virgin)

(Color for dry conditions unless otherwise noted.)

A1 0 to 2 inches-Pale brown (10YR 6/3) gravelly sandy loam, dark grayish brown (10YR 4/2) when moist; weak fine platy structure; weak vesicular material between pebbles; soft, very friable, nonsticky, nonplastic; very few micro-roots, common fine interstitial pores; violently effervescent; $\mathrm{pH} 8.4$; abrupt smooth boundary. ( 2 to 6 inches thick.)

C1 2 to 12 inches-Very pale brown (10YR 7/3) gravelly sandy loam, dark brown (10YR 4/3) when moist, weak fine subangular blocky structure; soft, very friable, nonsticky, nonplastic; few fine and micro-roots; few fine interstitial pores; violently effervescent; $\mathrm{pH} 8.8$; clear smooth boundary. 18 to 18 inches thick.)

C2 12 to 24 inches-Very pale brown (10YR 7/3) very gravelly and cobbly sandy loam, dark brown (10YR 4/3) when moist; massive, soft friable, nonsticky, nonplastic; abundant very fine, micro-roots, and few fine roots; few fine interstitial pores; violently effervescent; pH 9.0; abrupt wavy boundary. 18 to 20 inches thick.) 
C3sica 24 to 40 inches-Very pale brown (10YR 7/3) very gravelly and cobbly sandy loam with silica-lime, dark brown (10YR 4/3) when moist; massive, soft, friable, nonsticky, nonplastic; few micro-roots and fine roots; violently effervescent; pH 9.0; clear smooth boundary. ( 8 to 24 inches thick.)

C4sicam 40 inchest-White (10YR 8/2) silica-lime hardpan, very pale brown (10YR 7/3) when moist; massive, very hard firm, nonsticky, nonplastic; violently effervescent; $\mathrm{pH} 9.2$.

Type Location: 300 feet east and 1,000 feet south of the southwest corner of WERL dairy farm in Area 15.

Range in Characteristics: Texture of the control section is coarse, ranging from gravelly sandy loam to very gravelly, and cobbly sandy loam modified by stones. The coarse fragment content varies from 10 to 30 percent with gravel usually predominating. Cobble content is normally about 10 percent, but may vary from 5 to 20 percent. The dry consistence of the silica Cca horizons range from soft to very hard. The coarse fragments in the silica Cca horizons are always at least lime coated on their undersides, but may have discontinuous weakly lime-cemented bridging. Any profile will include a distinct silica Cca horizon within 24 to 40 inches of the surface. This soil has a silica lime hardpan at a depth between 36 and 48 inches.

Setting: Banded soils occur on nearly level to gently sloping alluvial fans. The sediments are gravelly alluvium of coarse texture that are high in tuff, rhyolite, granite and quartzite. The climate is semi-arid with mean annual rainfall of 6 to 12 inches, hot dry summers, and cool moist winters. Mean annual temperature is about $65^{\circ} \mathrm{F}$, average January temperature about $40^{\circ} \mathrm{F}$, and average July temperature about $80^{\circ} \mathrm{F}$. The annual growing season is about 150 to 180 days. 
Drainage and Permeability: Excessively drained to the hardpan and very slow through the pan. Runoff is very slow and permeability is rapid to very rapid.

Use and Vegetation: This soil is being used as range with a low carrying capacity. These soils support a good stand of blackbrush (Coleogyne romosissima), wolfberry (Lycium andersonii), small rabbitbrush (Chrysothamnus stenophylzus), winter fat (Eurotia Zanata), Nevada jointfir (Ephedra nevadensis), Indian ricegrass (Orhyzopsis hymenoides), Joshua tree (Yucca brevifolia), desert needlegrass (Stipa speciosa), and assorted annuals. The plant density is about 20 percent.

Distribution and Extent: Southern Nevada. This soil occurs on a small area of the survey.

Series Proposed: Nevada Test Site, Area 15, Nye County, Nevada, 1966. Banded is the name of a mountain near the WERL dairy farm on NTS. 
2. Butte: The Butte series comprises Typic Torrifluvents, member of a coarse sandy, mixed, calcareous, mesic family. Characteristically, the soils have dark brown moderately alkaline A horizons of sandy loam and brown or yellowish brown moderately alkaline $C$ horizons of gravelly sandy loam grading with depth into sandy, gravelly, and cobbly alluvium.

Typifying Profile: Butte loamy sandy irrigated pasture.

(Colors for dry conditions unless otherwise noted.)

A1 0 to 4 inches-Pale brown (10YR 6/3) sandy loam, dark brown (10YR 4/3) when moist; weak medium subangular blocky strucutre; soft, friable, nonsticky, nonplastic; very few micro-roots; common fine interstitial pores; violently effervescent; $\mathrm{pH}$ 8.4; abrupt smooth boundary. (3 to 8 inches thick.)

C1 4 to 10 inches-Very pale brown (10YR 7/3) loamy sand, yellowish brown (10YR 5/4) when moist; weak fine subangular blocky structure; soft, friable, nonsticky, nonplastic; few fine, medium, and microroots; common fine interstitial pores; violentiy effervescent; pH 8.4; clear smooth boundary. (4 to 12 inches thick.)

C2 10 to 16 inches-Light yellowish brown (10YR 6/4) gravelly loamy sand, yellowish brown (10YR 5/4) when moist; weak fine subangular blocky structure; soft, friable, nonsticky, nonplastic; plentiful microroots and few fine roots; common fine interstitial pores; violently effervescent; $\mathrm{pH} 8.6$; clear smooth boundary. (4 to 12 inches thick.)

C3 16 to 29 inches-Very pale brown (10YR 7/3) graveliy loamy sand, brown (10YR 5/3) when moist, weak fine subangular blocky breaking to single grain; loose, nonsticky, 
nonplastic, plentiful very fine, micro-roots and few fine roots; few interstitial pores; violently effervescent; $\mathrm{pH} 8.8$; clear smooth boundary. ( 8 to 20 inches thick.)

C4 29 to 39 inches-Pale brown (10YR 6/3) graveliy loamy sand, brown (10YR 5/3) when moist, massive; loose, nonsticky, nonplastic, few fine and microroots and few fine interstitial pores; violentiy effervescent; $\mathrm{pH} 8.8$; clear smooth boundary. ( 8 to 18 inches thick.)

C5 39 to 60 inchest-Light yellowish brown (10YR 6/4) graveliy loamy sand, dark brown (10YR 4/3) when moist; massive soft, friable, nonsticky, nonplastic; few fine and micro-roots; violently effervescent; $\mathrm{pH} 8.8$.

Type Location: Southeast corner of WERL dairy farm in Area 15.

Range in Characteristics: Texture of the control section is moderately coarse to coarse, ranging from fine sandy loam to sand and modified by grave 1, cobbles, or stones. The coarse fragment content varies from 10 to 30 percent with gravel usually predominating. Cobble content is normally about 10 percent, but may vary from 5 to 20 percent. Stones usually will not exceed 5 percent except on the ridges in the area. The $C$ horizon may have a silica-lime cementation.

Setting: Butte soils occur in nearly level to gently sloping alluvial fans. The sediments are gravelly alluvium of coarse texture that are high in tuff, rhyolite, granite, and some quartzite that have come mainly from igneous and metasedimentary rocks. The climate is semiarid with mean annual rainfal1 of 6 to 12 inches, hot dry summers, and cool moist winters. Mean annual temperature is about $65^{\circ} \mathrm{F}$, average January temperature about $40^{\circ} \mathrm{F}$, and average July temperature about $80^{\circ} \mathrm{F}$. The annual growing season is between 150 to 180 days. 
Drainage and Permeability: Well drained, with slow runoff and moderately rapid to rapid permeability. Infiltration may be moderate to rapid in cultivated areas.

Native Vegetation: Wolfberry (Lycium andersonii), small rabbitbrush (Chrysothamms stenophyzlus), Indian ricegrass (Orhyzopsis hymenoides), four-winged saltbush (Atriplex canescens), Joshua tree (Yucca brevifolia), winter fat (Eurotia lanata), desert needlegrass (Stipa speciosa), and assorted annuals. The plant density is about 20 percent, except in years having good rainfall when annuals predominate the site.

Use: Much of this soil is used on range with a low carrying capacity. Some of it is being used for cultivated crops such as alfalfa, barley, oats, and sudan grass by WERL.

Distribution and Extent: Southern Nevada and probably in parts of southeastern California, western Arizona, and southwestern Utah.

Series Proposed: Nevada Test Site, Area 15, Nye County, Nevada. Butte is the name of a hill on the Eleana Range inside NTS (Big Butte). 
3. Twin Peaks: The Twin Peaks series comprises Typic Torrifluvents, member of coarse loamy, mixed, calcareous, mesic family. Characteristically the soils have pale brown moderately alkaline $A$ horizons of fine sandy loam and very pale brown strongly alkaline $C$ horizons of fine sandy loam grading to gravelly loamy sand. This soil also has a buried B2 horizon that is light reddish brown with common fine distinct pinkish white silica-lime streaks and a texture of sandy loam. The B2b horizon is moderately alkaline.

Typifying Profile: Twin Peaks fine sandy loam.

(Colors for dry conditions unless otherwise noted.)

A1 0 to 5 inches-Pale brown (10YR 6/3) fine sandy loam, dark brown (10YR 4/3) when moist; weak medium subangular blocky structure; soft, friable, nonsticky, nonplastic; plentiful micro-roots and few fine roots; many fine interstitial pores; violently effervescent; pH 8.4; abrupt smooth boundary. ( 3 to 12 inches thick.)

C1 5 to 16 inches-Very pale brown (10YR 7/3) fine sandy loam, dark brown (10YR 4/3) when moist; weak medium subangular blocky structure; soft, friable, nonsticky, nonplastic; plentiful micro-roots and few fine roots; many fine interstitial pores; violently effervescent; pH 8.6 ; clear smooth boundary. ( 8 to 20 inches thick.)

C2 16 to 28 inches-Pale brown (10YR 6/3) gravelly sandy loam brown (10YR 5/3) when moist; massive, soft very friable, nonsticky, nonplastic; few fine roots; common fine interstitial pores; violently effervescent, $\mathrm{pH} 8.6$; clear smooth boundary. (8 to 24 inches thick.) 
B2b 28 to 48 inchest-Light reddish brown (5YR 6/4) sandy loam with common fine distinct pinkish white (5YR 8/2) silica-lime streaks, reddish brown (5YR 5/4) when moist; strong medium subangular blocky structure; hard, friable, slightly sticky, nonplastic: very few micro-roots; many medium and fine tubular pores; common thin clay films on peds and in pores; strongly effervescent; $\mathrm{pH} 8.4$.

Type Location: About 300 feet south and 600 feet east of the northeast corner of WERL dairy farm in Area 15.

Range in Characteristics: Texture of the control section is moderately coarse to coarse, ranging from sandy loam to gravelly loamy sand. The buried $B$ horizon may be found between 20 and 56 inches of the surface and may have a silica-lime cementation in the lower horizons.

Setting: Twin Peaks soils occur in nearly level to gently sloping alluvial fans. The sediments are sandy alluvium of moderately coarse texture that are high in tuff, rhyolite, granite and some quartzite that have come mainly from igneous and sedimentary rocks.

The climate is semi-arid with mean annual rainfall of 6 to 12 inches, hot dry summers, and cool moist winters. Mean annual temperature is about $65^{\circ} \mathrm{F}$, average January temperature about $40^{\circ} \mathrm{F}$, and average July temperature $80^{\circ} \mathrm{F}$; the annual growing season is between 150 and 180 days. Drainage and Permeability: Well drained, with slow runoff and moderately rapid permeability. Infiltration may be moderate to moderately rapid if cultivated.

Native Vegetation: Wolfberry (Lycium andersonii), blackbrush (CoLeogyne ramosissima), small rabbitbrush (Chrysothamnus stenophyzlus), Nevada joint-fir (Ephedra nevadensis), winter fat (Eurotia Lanata), desert needlegrass (Stipa speciosa), Joshua tree (Yucca brevifolia), Indian ricegrass (Oxhyzopsis hymenoides), bud sagebrush (Artemisia spinescens), 
and squirrel tail (Sitanion spp.). The plant density is about 20 percent, except in years having good rainfall when annuals predominate the site.

Use: All of this soil is used as range with a low carrying capacity. This soil would be well adapted for cultivated crops.

Distribution: Southern Nevada.

Series Proposed: Twin Peaks is the name of a mountain located inside NTS, Area 15, Nye County, Nevada. 
4. Thirsty: The Thirsty series comprises Typic Torrifluvents member of sandy skeletal, mixed, calcareous, mesic family. Characteristically the soils have dark brown moderately alkaline $A$ horizons of sandy loam and brown, or yellowish brown, moderately alkaline $C$ horizons of gravelly sandy loam grading with depth into sandy, gravelly and cobbly alluvium.

Typifying Profile: Thirsty cobbly sandy loam, irrigated pasture. (Colors for dry conditions unless otherwise noted.)

A1 0 to 5 inches-Pale brown (10YR 6/3) cobbly sandy loam, dark brown (10YR 4/3) moist; weak medium subangular blocky structure; soft, very friable; nonsticky, nonplastic; plentiful fine and medium roots, common fine interstitial pores; strongly effervescent; $\mathrm{pH} 8.4$; abrupt smooth boundary. ( 3 to 8 inches thick.)

C1 5 to 13 inches-Pale brown (10YR 6/3) cobbly sandy loam, dark brown (10YR 4/3) moist; weak fine subangular blocky; structure, soft; very friable; nonsticky, nonplastic; abundant micro-roots and plentiful fine roots; common fine interstitial pores; strongly effervescent, $\mathrm{pH} 8.4$; clear smooth boundary. (5 to 12 inches thick.)

C2 13 to 26 inches-Very pale brown (10YR 7/3) cobbly and gravelly loamy sand, brown (10YR 5/3) moist; massive; soft; ioose; nonsticky, nonplastic; plentiful fine, medium, and micro-roots; strongly effervescent, $\mathrm{pH} 8.6$; clear smooth boundary. (10 to 20 inches thick.) 
C3 26 to 60 inchestavery pale brown (10YR 7/3) very gravelly loamy sand, brown (10YR 5/3) moist; massive; loose: nonsticky, nonplastic; few micromroots and very few fine roots; slightly effervescent, pH 8.6.

Type Location: Nye County, Nevada; approximately center of WERL dairy farm in Area 15.

Range in Characteristics: Texture of the control section is moderately coarse to coarse, ranging from fine sandy loam to sand and modified by gravel, cobbles, or stones. The coarse fragment content varies from 20 to 50 percent with gravel usualiy predominating. Cobble content is normally about 20 percent but may vary from 5 to 30 percent. Stones usually will not exceed 5 percent except on the ridge running through the area, where they may be as high as 30 percent.

Setting: Thirsty soils occur in nearly level to gently sloping alluvial fans. The sediments are gravelly alluvium of coarse texture that are high in tuff, rhyolite, granite and some quartzite that have come mainly from igneous and metasedimentary rocks. The climate is semi-arid with mean annual rainfall of 6 to 12 inches, hot dry summers, and cool moist winters. Mean annual temperature is about $65^{\circ} \mathrm{F}$, average January temperature is about $40^{\circ} \mathrm{F}$, and average July temperature about $80^{\circ} \mathrm{F}$. The annual growing season is between 150 to 180 days.

Drainage and Permeability: Well to excessively drained with slow runoff and moderately rapid to apid permeability. Infiltration may be moderately rapid to rapid in cultivated areas.

Native Vegetation: Blackbrush (Coleogyne ramosissima), wolfberry (Iycium andersonii), small rabbitbrush (Chrysothamus stenophyizus), Nevada joint-fir (Ephedra nevadensis), four-winged saltbush (Atriplex canescens), bud sagebrush (Artemisia spinescens), Joshua tree (Yucca brevifolia), winter fat (Eurotia Zanata), Indian ricegrass (Orhyzopsis hymenoides), and desert needlegrass (Stipa speciosa). 
Use: Much of this soil is used as range with a very low carrying capacity. Some of this soil is being used for cultivated crops such as alfalfa, barley, oats, and sudan grass. Native plant density is about 15 percent, except in years having good spring rains when annuals predominate the site.

Distribution and Extent: Southern Nevada and probably in parts of southeastern California, western Arizona, and southwestern Utah. Series Proposed: Nevada Test Site, Area 15 on WERL dairy farm, Nye County Nevada, 1966. Thirsty is a name of a canyon near NTS. 


\section{BIBLIOGRAPHY}

1. Jackson, M. L., Soil Chemical Analysis. PrenticemHall, Inc. Englewood Cliffs, New Jersey. 1960. 498 pp.

2. Volborth, A., Total Instrumental Analysis of Rocks. Nevada Bureau of Mines, Report No. 6. 1963.

3. Munsell Color Company, Inc., Baltimore, Maryland. 
APPENDICES

Page

APPENDIX I. CLASSIFICATION AND CHARACTERISTICS OF SOIL

APPENDIX II. SOIL SYMBOLS WITH DESCRIPTION DESCRIBING

23

EACH DIGIT

APPENDIX III. SOIL CAPABILITY UNITS

APPENDIX IV. SOIL CLASSIFICATION

25

APPENDIX V. CONVENTIONAL MAPPING SYMBOLS FOR SOIL

SURVEY FIELD SHEET

APPENDIX VI. AERIAL MAP - AREA 15 WERL DAIRY FARM

27

APPENDIX VII. SOIL SURVEY MAPPING LEGEND

28

APPENDIX VIII. PHYSICAL ANALYSIS OF SOILS

APPENDIX IX. ANALYSIS OF FARM SOILS

APPENDIX $X$. GLOSSARY 
Appendix I. Classification and Characteristics of Soil

\begin{tabular}{|c|c|c|c|c|c|c|c|}
\hline Series & Texture & Permeability & Drainage & $\% \mathrm{CaCO}_{3}$ & $\frac{\text { Surface }}{\text { DRY }}$ & $\frac{\mathrm{e} \text { Soit }}{\text { Moist }}$ & Parant Material \\
\hline \multicolumn{8}{|c|}{ ZONAL } \\
\hline Banded & $\begin{array}{l}\text { Coarse } \\
\text { gravelly }\end{array}$ & $\begin{array}{l}\text { Rapid to } \\
\text { very rapid }\end{array}$ & Excessive & High & IOYR $6 / 3$ & IOYR $4 / 2$ & $\begin{array}{l}\text { Gravelly alluvium } \\
\text { from a wide variety } \\
\text { of igneous and } \\
\text { sedimentary rock. }\end{array}$ \\
\hline
\end{tabular}

\section{AZONAL}

$\approx$ Butte

Twin Peaks

lloderate

coarse

Moderate

rapid

Rapid to

very rapid

Well to

excessive

Mod-

erate

10YR 6/3 10YR 4/3 Mixed but dominantly

tuff, rhyolite,

granite and quartzite.

Well

Mod-

erate

IOYR $6 / 3$ IOYR $4 / 3$

Mixed but dominantly

tuff, rhyolite,

granite and quartzite.

$\begin{array}{lll}\text { Thirsty } & \text { Moderately } & \text { Moderate } \\ \text { coarse } & \text { rapid to } \\ \text { gravelly } & \text { rapid } \\ \text { cobbly } & \end{array}$

Well to

execssive

Mod-

erate
IOYR $6 / 3$ TOYR $4 / 3$

Mixed but dominantly

tuff, rhyolite,

granite and quartzite. 
Appendix II. Soil Symbols With Descriptions Describing Each Digit.

SYMBOLS:

$$
\frac{1557 *}{A-1 t}
$$

*1 = Depth of soil (over 60")

$S=$ Texture of soil

$5=$ Permeability of surface soil

7 = Permeability of substratum

$+A=$ Slope (which is none to slight)

$1=$ Erosion (which is slight)

1553 Very deep fine sandy loam over sandy loam, nearly level to

$\overline{A-2}$ slightly sloping with moderate erosion.

1557 Very deep sandy loam over coarse sands, gravel, and some cobbles,

$\overline{A-T}$ nearly level to slightly sloping, with slight erosion.

lgS6 Very deep gravelly sandy loam throughout with few cobbles, nearly

A-1 level to siightly sloping, with slight erosion.

lgS57 Very deep gravelly sandy loam underlain with coarse sand and

$\overline{A-1}$ cobbles, nearly level to slightly sloping with slight erosion.

1vgS7 Very deep very gravelly sandy loam over coarse sands and cobbles, $\overline{\mathrm{B}-2}$ gently sloping with moderate erosion.

1 kS57 Very deep cobbly and grave7ly sandy loam over coarse sands and $\overline{\mathrm{B}-2}$ gravel, gently sloping with moderate erosion.

3gS5R Moderately deep gravelly sandy loam over cemented hardpan (caliche) $\overline{A-2}$ nearly level to slightly sloping with moderate erosion.

4gS5R Shallow gravelly sandy loam over cemented silica hardpan (caliche) A-2 nearly level to slightly sloping with moderate erosion.

4KS5R Shallow cobbly and gravelly sandy loam over cemented silica hard$\overline{B-2}$ pan (caliche) gently sloping with moderate erosion. 
Appendix III. Soil Capability Units.

1. IIS4 Very deep (over $36^{\prime \prime}$ ) moderately coarse textured soils, with sand substrata or gravelly loamy sand and gravelly sandy loam substratum; moderate available water holding capacity $\left(1.0\right.$ to $\left.1.5^{\prime \prime} / \mathrm{ft}\right)$; nearly level slopes; well drained, slight erosion.

2. IVS4 Very deep (over 36") gravelly moderately coarse textured soils; well drained; low available water holding capacity (.75 to $7 " \mathrm{ft}$ ) nearly level, slight erosion.

3. VIIS4 Moderately deep (20 to $36^{\prime \prime}$ ) gravelly and very gravelly moderately coarse and coarse textured soils; well to excessively drained; low to very low available water holding capacity; nearly level to gently sloping, moderate erosion.

4. VIIS7 Very deep (over 36") stony and cobbly moderately coarse textured soils; well drained; low available water holding capacity; gently sloping, moderate erosion.

5. VIIS8 Moderately deep to shallow (10 to 36") gravelly and very gravelly moderately coarse textured soils; over silica lime hardpan; very low to low available water holding capacity $(.75$ to $111 / \mathrm{ft})$ well drained, nearly level, moderate erosion.

6. VIICK Very deep (over 60") moderateiy coarse textured soils; well drained; high available water holding capacity; nearly level slopes. Irrigation water not available; moderate erosion. 
Appendix IV. Soil Classification.

\begin{tabular}{|c|c|c|c|}
\hline \multirow{2}{*}{$\begin{array}{l}\text { Soit } \\
\text { Series }\end{array}$} & \multirow{2}{*}{$\begin{array}{l}1938 \\
\text { Yearbook }\end{array}$} & \multicolumn{2}{|c|}{ 7th Approximation } \\
\hline & & Subgroup & Family \\
\hline Banded & Calcisol & Typic Durorthids & $\begin{array}{l}\text { Sandy, mixed, calcareous, } \\
\text { mesic. }\end{array}$ \\
\hline Butte & Alluvial & Typic Torrifluvents & $\begin{array}{l}\text { Coarse sandy, mixed, } \\
\text { calcareous, mesic. }\end{array}$ \\
\hline Twin Peaks & Alluvial & Typic Torrifluvents & $\begin{array}{l}\text { Coarse loamy mixed } \\
\text { calcareous, mesic. }\end{array}$ \\
\hline Thirsty & Alluvial & Typic Torrifluvents & $\begin{array}{l}\text { Sandy skeletal, mixed } \\
\text { calcareous, mesic. }\end{array}$ \\
\hline
\end{tabular}


APPENDIX V. CONVENTIONAL MAPPING SYMBOLS FOR

SOIL SURVEY FIELD SHEET

MAPPING SYMBOLS FOR SURVEY FIELD SHEET

Hard Surfaced Roads - I I W

Good Gravel Road

Poor Dirt Road

ニニニニニニニニニニニニニニニニ

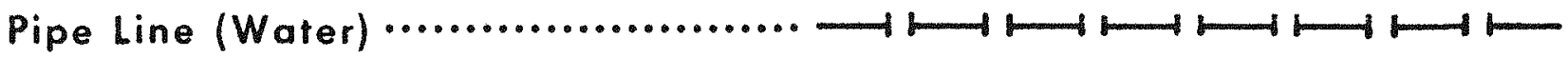

Power-transmission Line

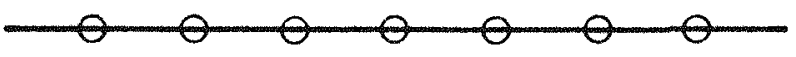

Wells

Well

Intermittent Streams ..........................

Soil Survey Area Boundary.............. -

Soil Boundary.

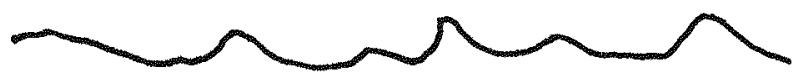

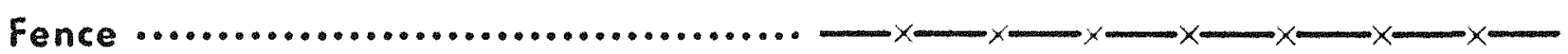




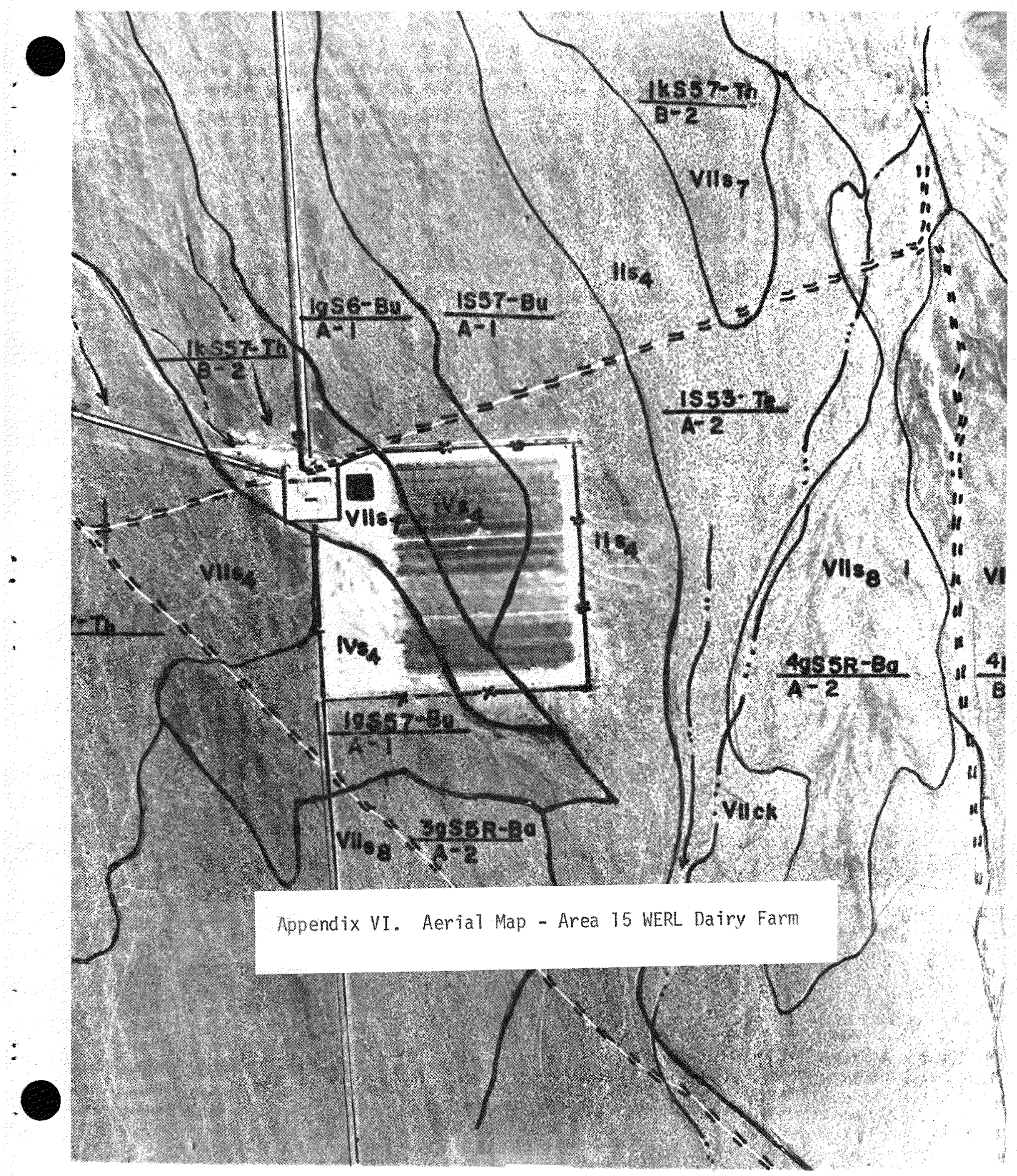




\section{APPENDIX VII. SOIL SUPVEY MAPPING LEGEND}

This legend lists and defines the mapping symbols for soil, slope, erosion, and other physical land factors which will be used for soil surveys on the range area of ITS.

\section{Order of Symbols}

The land mapping symbol shows soil characteristics, slope erosion, and additional land factors of wetness, salinity, and overtlow if significant. Symbols are written in fractional form with soil characteristics in the numerator and slope, erosion, and additional land factors in the denominator. Soil series will be shown by attaching an identifying symbol to the numerator of the fractional symbol.

\section{Delineations}

Soil Type and Phase Boundary: Solid black lines. Land Use Boundary: Dashed lines (1/8")

\section{Symbols for Soil Characteristics}

Order of symbols to show soil characteristics is as follows: First, the effective depth, then, the texture; then, the permeability of the upper subsoil; then the permeability of the lower subsoil; finally, the type of underlying material if significant.

Type of underlying material will be shown whenever it limits the effective depth. The permeability of the lower subsoil will be omitted when this is not significantly different from that of the upper subsoil. Permeability of lower subsoil is also omitted when depth symbol is 4 . Permeability of both upper and lower subsoil is omitted when depth symbol is 5 . 
ETFCCTIVE DEPTH

Symbor.

1

2

3

4

5

TEXTURE

Symbol

H

$F$

II

S

L

C

$x$
Range

Over 60 inches

36 - 60 inches

24 - 36 inches

12 - 24 inches

Less than 12 inches
Descriptive Term

Very deep.

Deep

Moderately deep

Shallow

Very shallow
Included Texture Classes

Clay, silty clay

Sandy clay, silty

clay loam

Silt loam, loam, very fine sandy loam

Fine sandy loam, sandy loam

Loamy fine sand, loamy very fine sand, loamy sand

Very coarse

Fine sand, sand, and coarse sand

MODIFIERS OF TEXTURE (Placed before texture symbol)

Symbol

g

$r$

S
Descriptive Term

Gravelly

Very graveliy

Stony or cobbly
Range

Limiting crop adaptation and moistureholding capacity Enough gravel to prevent cultivation

Enough stone to hinder cultivation 


\begin{tabular}{cl} 
Symbol & \multicolumn{1}{c}{ class } \\
\hline 2 & Slow \\
3 & Moderately slow \\
4 & Moderate \\
5 & Moderately rapid \\
6 & Rapid \\
7 & Very rapid
\end{tabular}

Approximate Rate

(Inches Per Hour)

$$
.05-2.0
$$

$.20-.80$

$.80-2.50$

$2.50-5.00$

$5.00-10.00$

More than 10.00
Probable

Texture

$H$ or $F$

$F$ or $M$

$M$ or $S$

$S$

L

C

TYPE of LIMITING or UNDERLYING MATERIAL

Symbol

V

$\mathrm{R}$

Y

Z

Type of Material

Lacustrine sediments

Lime or lime-silica hardpan

Dense very slowly permeable clay

Gravel

\section{STope}

One set of slope classes will be mapped. In symbolizing slope, slope class letters only will be placed in the fractional symbol. For hummocky micro-topography a double slope class letter will be used.

STope Class

Symbol

A

B

$A B$

C

$\mathrm{BC}$

DE

$E F$

AA

BB
Pange

$0-2 *$

$2-4$

$0-4$

$4-8$

$2-8$

$8-30$

$15-45+$

$0-2$

$2-4$
Descriptive Term

Nearly level

Gently sloping

Hearly level to gently sloping

Moderately sloping

Gently to moderately sloping

Strongly sloping to steep

Steep to very steeply sloping

ilearly level with hummocks

Gently sloping with hummocks

*Percent of slope 


\begin{tabular}{ll} 
Symbo1 & Descriptive Term \\
\hline 1 & ivo apparent or slight erosion \\
2 & Moderate erosion \\
4 & Very severe erosion \\
if & Very severe wind erosion (1arge dunes)
\end{tabular}

\section{Degree of Wetness}

Symbol

Descriptive Term and Range

W1

Moderately well drained: Profile is wet for a small but significant part of the time, usually because of a slowly permeable layer within or immediately beneath the solum, a relatively high or intermittentiy high water table (usually below 5 feet), surface additions of water by runoff from areas higher up the slopes, or a combination of those conditions. (This class is particularly difficult to assess in drier climates or where winter rainfall occurs when temperatures are low enough to almost inhibit growth.) Evidence includes somewhat thicker and darker A horizons as contrasted to those of well drained soils (grass vegetation), mottiing in the lower $B$ horizons or within 36 to 60 inches of the surface or both.

1.12

Imperfectly or somewhat poorly drained: Soil is wet for significant periods, but not all of the time, usually because of a slowly permeable layer or a high water table. Field evidences of imperfect drainage are the presence of a water table (at depths of 36 to 60 inches), distinct gleying within 18 to 36 inches of the surface ususually thick and dark $A$ horizons (related to abundant growth of coarser grasses and slower decomposition rates because of wetness), pronouced accumulations of water soluble salts within 36 inches, or a combination of these. Arti icial drainage is needed for the growth of most deep rooted crops and many others that are sensitive to poor aeration. irainace may also be necessary to maintain a favorable salt balance.

W3 Poorly drained: The soil remains wet much of the time with the water table seasonally near the surface for prolonged intervals. Field evidences of poor drainage are the presence of a high water table (at depths of 18 to 36 inches), gleying near the surface (above 18 inches), and pronouced 
Symbol Descriptive Term and Range (Continued)

W3 accumulations of water soluble salts at or near the surface in saline areas. Soils usually lack peaty or mucky surface horizons. Drainage is necessary for the growth of important crops. Grazing is possible most of the time, and hay can usaully be harvested.

W4 Very poorly drained: The water table remains at or near the surface a greater part of the time. Field evidences of very poor drainage are the presence of a very high water table (at depths above 18 inches), a peaty or mucky surface horizon, and gleying at or near the surface (i.e. hues yellower than 10Yp and/or chromas of $/ 2$ or less and/or distinct discontinuous phase of the pattern). Soils that are very poorly drained due to a moving water table may have oxidized rather than reduced colors because of dissolved oxygen in the water. Drainage is a minimum prerequisite for the growth of important crops. Usually grazing is possible, at least seasonally, and hay may be harvested in drier years.

\section{Salinity}

Symbol

No symbot

$\$ 1$

S2

53

3

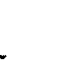

$$
\text { Range }
$$

Range-Conductivity

$\left(\begin{array}{lll}* & \text { Salt })\end{array}\right.$

Saturation Extract

(EC $10^{\prime} \mathrm{A} 25^{\circ} \mathrm{C}$ )

Descriptive Term

Less than 0.15

Less than 4

Free
$0.15-0.35$
$4-8$
$0.35-0.65$
$8-15$

slight

Moderate

0.65 - or greater 15 or greater

Severe

\section{Alkalinity}

Symbol

Descriptive Term

ito symbol

Free

al

stight to moderate

a2

Severe 
Overflow

Symbol

f)

Descriptive Term

Occasional overflow 
Appendix VIII. Physical Analysis of Soils.

\begin{tabular}{|c|c|c|c|c|c|c|c|c|c|c|c|}
\hline & & & & Gravel & & & Particl & e-size Distr & ition & & \\
\hline Soil & $\begin{array}{l}\text { Hori- } \\
\text { zon }\end{array}$ & Depth & Textural Class & & $\begin{array}{l}\text { Very coarse } \\
\text { sand }(2.0 \\
-1.0 \mathrm{~mm})\end{array}$ & $\begin{array}{l}\text { Coarse sand } \\
(1,0-0.5 \\
\text { mm) }\end{array}$ & $\begin{array}{l}\text { Medfum } \\
\text { sand }(0.5- \\
0.25 \mathrm{~mm})\end{array}$ & $\begin{array}{l}\text { Fine } \\
\text { sand }(0.25 \\
-0.10 \mathrm{~mm})\end{array}$ & $\begin{array}{l}\text { Very fine } \\
\text { sand }(0.10 \mathrm{~m} \\
0.05 \mathrm{~mm})\end{array}$ & $\begin{array}{l}\text { Sitt } \\
(0.05 \\
-0.002 \mathrm{~mm})\end{array}$ & $\begin{array}{l}\text { Clay< } \\
(0,002 \\
\text { min })\end{array}$ \\
\hline
\end{tabular}

$\begin{array}{llll}\text { Banded, gravelly } & A_{1} & 0-2^{\prime \prime} & \text { gravelly sandy loam } \\ \text { sandy ioam } & C_{1} & 2-12^{\prime \prime} & \text { gravelly sandy loam }\end{array}$

sandy loam Area $15 \quad C_{1} \quad 12-24^{\prime \prime}$ gravelly sandy loam 23

$\omega$ Farm NTS Area $15 C_{2}$ sica 24-40" very gravelly and cobbly sandy loam

Survey Hole No. 8 C $\mathrm{C}_{4}$ sicam $40^{\prime \prime}$ silica-lime hardpan

$\begin{array}{lll}\text { Butte, loamy } & A_{1} & 0-4^{\prime \prime} \\ \text { Sand Loamy sand } \\ \text { Location: Area 15 } & C_{1} & 4-10^{\prime \prime} \text { Loamy sand } \\ \text { Farm NTS } & C_{2} & 10-16^{\prime \prime} \text { gravelly loamy sand } \\ \text { Survey Hole No. } 1 & C_{3} & 16-29^{\prime \prime} \text { gravelly loamy sand } \\ & C_{4} & 29-39^{\prime \prime} \text { gravelly loamy sand } \\ & C_{5} & 39-60^{\prime \prime} \text { gravelly loamy sand }\end{array}$

Twin Peaks, fine $A_{1} \quad 0-5 "$ fine sandy loam

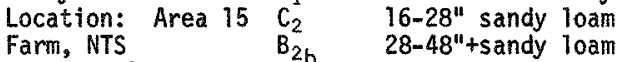
sandy loam $15 C_{1} \quad 5-16^{\prime \prime}$ fine sandy loam

25
23
25
61

6
6
11
12

9
8
11
15

12
13
15
13

23
24
16
15

$\begin{array}{ll}12 & 13 \\ 15 & 14 \\ 22 & 12 \\ 23 & 26 \\ 32 & 11 \\ 32 & 10\end{array}$

13
14
12
26
11
10

9
11
23
18

Survey Hole No. 6

$\begin{array}{ll}15 & 18 \\ 14 & 19 \\ 25 & 22 \\ 34 & 13 \\ 23 & 20 \\ 18 & 25 \\ & \\ 17 & \\ 17 & 23 \\ 24 & 21 \\ 15 & 20 \\ & 23\end{array}$

$\begin{array}{lr}18 & 19 \\ 19 & 20 \\ 22 & 15 \\ 13 & 4 \\ 20 & 19 \\ 25 & 15 \\ & \\ & \\ 23 & 22 \\ 21 & 20 \\ 20 & 14 \\ 23 & 11\end{array}$

22
21
14
12

$\begin{array}{rr}22 & 6 \\ 21 & 7 \\ 21 & 12 \\ 20 & 13\end{array}$

$\begin{array}{rl}19 & 2 \\ 20 & 1 \\ 15 & 1 \\ 4 & \\ 19 & 1 \\ 15 & \\ & \\ 22 & \\ 20 & \\ 14 & \\ 11 & \end{array}$

$\begin{array}{rr}20 & 10 \\ 18 & 10 \\ 19 & 10 \\ 8 & 10 \\ 12 & 15 \\ 12 & 14 \\ & \\ 2 & \\ 2 & 18 \\ 5 & 21 \\ 2 & 14 \\ & 27\end{array}$

$\begin{array}{ll}10 & \\ 10 & 5 \\ 10 & 5 \\ 10 & 5 \\ 15 & 5 \\ 14 & 5\end{array}$

$\begin{array}{ll}18 & 12 \\ 21 & 11 \\ 14 & 10 \\ 27 & 14\end{array}$


Appendix VIII. Physical Analys is of Soils. (Continued)

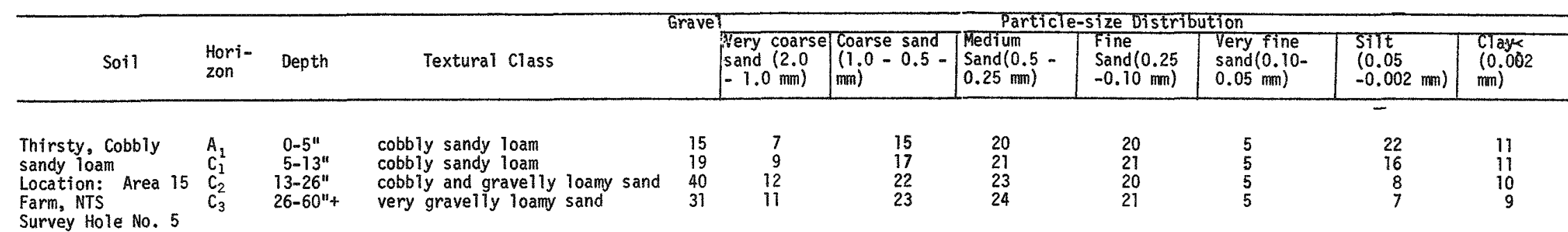




\section{APPENDIX IX, ANALYSIS OF FARM SOILS}

\begin{tabular}{|c|c|c|c|c|}
\hline Soil Code & A & B & c & D \\
\hline Name & Butte & Thirsty & Butte & Butte \\
\hline Soil Survey Code & $\frac{1 \mathrm{gS} 57}{A-1}$ & $\frac{1 k S 57}{B-2}$ & $\frac{1557}{A-1}$ & $\frac{1956}{A-1}$ \\
\hline Capability Unit & IVs 4 & VIIs 7 & IIS4 & IVs 4 \\
\hline $\begin{array}{l}\text { Cation Exchange Cap. } \\
(\mathrm{meq} / 100 \mathrm{~g})\end{array}$ & 12.7 & 13.3 & 12.9 & 12.3 \\
\hline \multicolumn{5}{|l|}{$\begin{array}{c}\text { Exchangeable Cations } \\
(\text { meq } / 100 \mathrm{~g})\end{array}$} \\
\hline $\begin{array}{l}\mathrm{Ca} \\
\mathrm{Mg} \\
\mathrm{Na} \\
\mathrm{K}\end{array}$ & $\begin{array}{l}4.6 \\
0.7 \\
1.3 \\
3.9\end{array}$ & $\begin{array}{l}4.7 \\
0.8 \\
1.4 \\
4.1\end{array}$ & $\begin{array}{l}4.3 \\
0.8 \\
1.4 \\
3.6\end{array}$ & $\begin{array}{l}4.2 \\
0.8 \\
1.5 \\
3.9\end{array}$ \\
\hline $\begin{array}{l}\text { Conductivity } \\
\text { (mmhos) }\end{array}$ & 12.4 & 12.9 & 11.4 & 11.6 \\
\hline \multirow[t]{2}{*}{$\mathrm{pH}$} & 8.4 & 8.2 & 8.3 & 8.2 \\
\hline & \multicolumn{4}{|c|}{ TOTAL ANALYSIS } \\
\hline $\begin{array}{l}\text { Carbonates } \% \text { as } \\
\mathrm{CaCO}_{3} \text { equivalents }\end{array}$ & $9.9 \%$ & $3.8 \%$ & $9.9 \%$ & $9.9 \%$ \\
\hline $\begin{array}{l}\mathrm{K} \\
\mathrm{Ca} \\
\mathrm{Na} \\
\mathrm{S} \\
\mathrm{Ti} \\
\mathrm{CI} \\
\mathrm{Mn} \\
\mathrm{Fe} \\
\mathrm{AT} \\
\mathrm{SiO}_{2} \\
\mathrm{Cu} \\
\mathrm{Zn} \\
\mathrm{Mo} \\
\mathrm{Mg} \\
\mathrm{N} \\
\text { Phosphate }\end{array}$ & $\begin{array}{l}4.9 \\
4.7 \\
0.62 \\
0.066 \\
0.119 \\
0.031 \\
0.09 \\
1.9 \\
4.62 \\
51.5 \\
0.045 \\
0.011 \\
0.0039 \\
1.6 \\
0.0035 \\
0.0072\end{array}$ & $\begin{array}{l}5.2 \\
5.3 \\
0.67 \\
0.076 \\
0.133 \\
0.031 \\
0.09 \\
2.1 \\
4.95 \\
53.2 \\
0.047 \\
0.011 \\
0.0112 \\
1.9 \\
0.0032 \\
0.004\end{array}$ & $\begin{array}{l}4.9 \\
4.2 \\
0.62 \\
0.086 \\
0.141 \\
0.030 \\
0.08 \\
2.1 \\
5.39 \\
54.7 \\
0.047 \\
0.011 \\
0.0112 \\
1.4 \\
0.0036 \\
0.0056\end{array}$ & $\begin{array}{l}4.9 \\
4.7 \\
0.63 \\
0.082 \\
0.138 \\
0.030 \\
0.08 \\
2.1 \\
5.08 \\
52.8 \\
0.047 \\
0.011 \\
0.0081 \\
1.6 \\
0.0037 \\
0.006\end{array}$ \\
\hline
\end{tabular}




\section{APPENDIX X。 GLOSSARY}

$A B C$ soil. A soil that has a complete profile, including an $A, B$, and $C$ horizon.

$A C$ soil. A soil that has an $A$ and $C$ horizon but no $B$ horizon. Commonly such soils are immature, as those developing from alluvium or those on steep, rocky slopes.

Aeration, soil. The exchange of air in soil with air from the atmosphere. The air in a well-aerated soil is similar to that in the atmosphere; but, that in a poorly aerated soil is considerably higher in carbon dioxide and lower in oxygen.

Alluvial fan. A fan-shaped deposit of sand, gravel, and fine material dropped by a stream where its gradient lessens abruptly.

Alluvium. Fine material, such as sand, silt, or clay, that has been deposited on land by streams.

Aspect (forestry). The direction toward which a slope faces. Synonym: Exposure.

Available moisture capacity. The difference between the amount of water in a soil at field capacity and the amount in the same soil at the permanent wilting point. Commoniy expressed as inches of water per inch depth of soil.

Badlands. Areas of rough, irregular, denuded land in which most of the surface is occupied by ridges, gullies, and deep channels.

Bedrock. The solid rock that underlies the soil and other unconsolidated material or that is exposed at the surface.

Buried soil. A developed soil, once exposed but now overlain by more recentily formed soil.

Calcareous soil. A soil containing enough calcium carbonate (often with magnesium carbonate) to effervesce (fizz) visibly when treated with cold di7ute hydrochloric acid.

Caliche. A more or less cemented deposit of calcium carbonate in many soils of warm-temperature areas, as in the soutnwestern stites. The material may consist of soft, thin layers in the soil or of hard, thick beds just beneath the solum or it may be exposed at the surface by erosion.

Clay. As a soil separate, the mineral soil particles less than 0.002 millimeter in diameter. As a soil textural class, soil material that is 40 percent or more clay, less than 45 percent sand, and less than 40 percent silt. 
Clay film. A thin coating of clay on the surface of a soil aggregate. Synonyms: Clay coat, clay skin.

Claypan. A compact, slowly permeable soil horizon that contains more clay than the horizon above and below it. A claypan is commoniy hard when dry and plastic or stiff when wet.

Coarse fragments. Minerals or rock particles more than 2 millimeters in diameter.

Coarse-textured soil. Sand and loamy sand.

Complex, soil. A mapping unit consisting of different kinds of soils that occur in such small individual areas or in such an intricate pattern that they cannot be shown separately on a publishable soil map.

Consistence, soil. The feel of the soil and the ease with which a lump can be crushed by the fingers. Terms commonly used to describe consistence are--

Loose. Noncoherent; will not hold together in a mass.

Friable. When moist, crushed easily under gentle to moderate pressure between thumb and forefinger and can be pressed together into a lump.

Firm. When moist, crushed under moderate pressure between thumb and forefinger, but resistance is distinctly noticeable.

Plastic. When wet, readily deformed by moderate pressure but can be pressed into a lump; will form a wire when rolled between the thumb and forefinger.

Sticky. When wet, adheres to other material; tends to stretch somelwat and pull apart, rather than pull free from other material. Hard. When dry, moderately resistant to pressure; can be broken with difficulty between thumb and forefinger.

Cemented. Hard and brittle; little affected by moistening.

Continental climate. The climate in areas distant from the ocean: characterized by considerable variation in temperature and in other weather conditions.

Contour. An imaginary line connecting points of equal elevation on the surface of the soil.

- Dolomite. Rock consisting mainly of magnesium carbonate and calcium carbonate; Timestone or marble with much magnesium carbonate in it.

Dune. A mound or ridge of loose sand piled up by the wind.

Duripan. Subsurface horizon that is cemented by silica, usually opal or microcrystalline form of silica, to the point that fragments from the air-dry horizon will not slake in water or acid.

Erosion. The wearing away of land surface by wind, running water, and other geological agents.

Erosion pavement (geology). A layer of coarse fragments of gravel or stones on the surface of the ground, which remains after the fine particles are removed by erosion. 
Fine-textured soils. Moderately fine textured: Clay loam, sandy clay loam, silty clay loam; fine-textured; sandy clay, silty clay, and clay. Roughly, soil that contains 35 percent or more of clay.

Flood plain. Nearly level land, consisting of stream sediment, that borders a stream and is subject to flooding unless protected artificially.

Fluvial. Flood plains.

Forage. Plant material that can be used as feed by domestic animals; it may be grazed or cut for hay.

Genesis, soil. The manner in which the soil originated, with special reference to the processes responsible for the development of the solum, or true soil, from the unconsolidated parent material.

Granite. A very hard, igneous rock, usually gray or pink, consisting chiefly of crystalline quartz, feldspar, and mica.

Gravelly soil material. From 15 to 50 percent of material by volume, consists of rounded or angular rock fragments that are not prominently flattened and are up to 3 inches in diameter.

Grazing capacity. The maximum number of animals or animal units per acre, or acres per animal unit, that a grazing area can support adequately without deterioration; sometimes called carrying capacity.

Gully. A miniature valley with steep sides cut by running water through which water ordinarily runs only after rains. The distinction between gully and rill is one of depth. A gully generally is an obstacle to farm machinery and is too deep to be obliterated by normal tillage, whereas, a rill is of lesser depth and can be smoothed over by ordinary tillage.

llardpan. A hardened or cemented soil horizon, or layer. The soil material may be sandy or clayey, and it may be cemented by iron oxide, silica, calcium carbonate, or other substances.

Horizon, soil. A layer of soil, approximately parallel to the surface, that has distinct characteristics produced by soil-forming processes. The relative position of the several soil horizons in a typical soil profile, and their nomenclature, are as follows:

$A_{0}$ Organic debris, partly decomposed or matted.

$A_{1}$ A dark-colored horizon having a fairly high content of organic matter mixed with mineral matter.

$A_{2}$ A light-colored horizon, often representing the zone of maximum leaching where podzolized; absent in wet, dark-colored soil.

$A_{3}$ Transitional to $B$ horizon but more like $A$ than $B$; sometimes absent.

$B_{1}$ Transitional to $B$ horizon but more like $B$ than $A$; sometimes absent.

$B_{2} A$ usually darker colored horizon, which often represents the zone of maximum illuviation where podzolized.

$\mathrm{B}_{3}$ Transitional to $\mathrm{C}$ horizon. 
The i horizons make up a zone of eluviation, or leached zones. The $B$ horizons make up a zone of illuviation, in which clay and other materials have accumulated. The $A$ and $B$ horizons, taken together, are called the solum, or true soil.

Hue. One of the three variables of color. The dominant spectral (rainbow) color; it is related to the dominant wavelength of the light. See Munsell notation.

Igneous rock. Rock that has been formed by the cooling of molten mineral material. Example: Granite, syenite, diorite, and gabbro.

Illuviation. The accumulation of material in a soil horizon through the deposition of suspended material and organic matter removed from horizons above. Since part of the fine clay in B horizon (or subsoil) of many soils has moved into the $B$ horizon from the $A$ horizon above, the $B$ horizon is called an illuvial horizon.

Indicator plants (ecology). Plants that give reliable information concerning present condition and past history of an area as to soil, alkalinity, salinity, climate, depth to water table, overgrazing, fire, and the use to which the area is best adapted.

Inherited soil characteristic. Any characteristic of a soil that results directly from the nature of the material from which it was formed, as contrasted to characteristics that are wholly or partly the result of soil-forming processes acting on parent material. For example, some soils are red because the parent material was red, but the color of most redd soils is the result of the soil-forming processes.

Lacustrine deposit (geology). Material deposited in lake water and exposed by lowering of the water level of elevation of the land.

Land. The total natural and cultural environment within which production taken place. Land is a broader term than soil. In addition to soil, it applies to mineral deposits and vater supply; location in relation to centers of commerce and population; the size of the individual tracts or holdings; and the existing plant cover works of improvement, and the like.

Land classification. The classification of units of land for the purpose of showing their relative suitabilities for some specific use.

Leached layer. A layer from which the soluble materials have been dissolved and washed away by percolating water.

Lime. Chemically, lime is calcium oxide ( $\mathrm{CaO}$ ), but its meanirg has been extended to include all limestone-derived materials applied to neutralize acid soils. Agricultural lime can be obtained as ground limestone, hydrated lime, or burned lime, with or without magnesium minerais. Basic slag, oystersheils, and inarl also contain calcium.

Lime concretion. An aggregate cemented by the precipitation of calcium carbonate $\left(\mathrm{CaCO}_{3}\right)$. 
Mechanical analysis (soils). The percentare of the various sizes of individual mineral particles, or separates in the soil. Mlso a laboratory method of determining soil texture.

Medium-textured soil. Soil of very fine sandy loam, loam, silt loam, or silt texture.

Mesic. Temperature range-less than near annual $59^{\circ} \mathrm{F}$ greater than the mean annual $47^{\circ} \mathrm{F}$ medium temperature between hot desert and cold up lands.

Mica. Primary alumino-silicate minerals in which two silica layers alternate with one alumina layer. The layers separate readily into thin sheets or flakes.

Micromorganisms. Forms of life that are either too small to be seen with the unaided eye or are barely discernible.

Montmorillonite. A fine, platy, alumino-silicate clay mineral that expands and contracts with the absorption and loss of water. It has a high cation-exchange capacity and is plastic and sticky when moist.

Morphology, soil. The makeup of the soil, including the texture, structure, consistence, color and other physical, chemical, mineralogical, and biological properties of the various horizons that make up the soil profile.

Mottled. Irregularly marked with spots of different colors that vary in number and size. Mottling in soils usually indicates poor aeration and lack of drainage. Descriptive terms are as follows:

Mbundance--few, common, and many; size--fine, medium, and coarse: and contrast--faint, distinct, and prominent. The size measurements are these: fine less than 5 millimeters (about 0.2 inch) in dianeter along the greatest dimension; medium, ranging from 5 millimeters to 15 millimeters (about 0.2 to 0.6 inch) in diameter, along the greatest dimension; and coarse, more than 15 millimeters (about 0.6 inch) in diameter along the greatest dimension.

Munsell notation. A system for designating color by degrees of the three simple variables--hue, value and chroma. For example, a notation of 10YR $6 / 4$ is a color with a hue of 10YR, value of 6 and a chroma of 4 .

Natural drainage. Refers to moisture conditions that existed during the development of the soil, as opposed to altered drainage, which is commonly the result of artificial drainage or irrigation but may be caused by the sudden deepening of channels or the blocking of drainage outlets. Several different classes of natural drainage are

Excessively drained soils are comonty very porous and rapidly permeable and have a low water-holding capacity.

Somewhat excessively drained soils are also very permeable and are free from motting throughout their profile.

Well-drained soils are nearly free from mottling and are commonly of intermediate texture. 
Moderately well-drained soils cormonly have a slowly permeable layer in or immediately beneath the solum. They have uniform color in the $A$ and upper $B$ horizons and have mottiling in the lower $B$ and the $C$ horizons.

Imperfectly or somewhat poorly drained soils are wet for significant periods but not all the time, and in podzolic soils commonly have mottlings below 6 to 16 inches, in the lower $A$ horizon and in the $B$ and $C$ horizons.

Poorly drained soils are wet for long periods and are light gray and general7y mottled from the surface downward, although mottling may be absent or nearly so in some soils.

Very poorly drained soils are wet nearly all the time. They have a dark-gray or black surface layer and are gray or light gray, with or without mottling, in the deeper parts of the profile.

Neutral soil. In practice, a soil having a pH value between 6.6 and 7.3. Strictly speaking, a soil that has a pH value of 7.0 .

Organic matter. A general term for plant and animal material, in or on the soil, in all stages of decomposition. Readily decomposed organic matter is often distinguished from the more stable forms that are past the stage of rapid decomposition.

Organic soil. A general term applied to a soil or to a soil horizon that consists primarlly of organic matter, such as peat soils, mulch soils, and peaty soil layers. In chemistry, organic refers to the compounds of carbon.

Pan. A layer in a soil that is firmly compacted or very rich in clay. Frequently the word "pan" is combined with other words that more explicitly indicate the nature of the layers; for example, hardpan, fragipan, and claypan.

Parent material (soil). The horizon of weathered rock or partiy weathered soil material from which soil has formed; horizon $C$ in the soil profile.

Ped. An individual naturäl soil aggregate, such as a crumb, a prism, or a block in contrast to a clod.

Permeability, soil. The quality of a soil horizon that enables water or air to move through it. Terms used to describe permeability are as follows: very slow, slow, moderately slow, moderate, moderately rapid, rapid, and very rapid.

pH. A numerical means for designating relatively yeak acidity and alkalinity, as in soils aid other biological systems. A pH value of 7.0 indicates precise neutrality; a higher value, aikalinity; an and a lower value, acidity.

Phase soil. A subdivision of a soil type, series, or other unit in the soil classification system made because of differences in the soil that affect its management but do not affect its classification in the natural Tandscape. A soil type, for example, may be divided 
into phases because of differences in slope, stoniness, thickness or some other characteristic that affects management.

Physical properties of soils. Properties related to or caused by the forces and operations of physics.

Plant density. The average number of plants per area sampled.

Plastic (soil consistence). Capable of being deformed without being broken.

Plastic limit (soil engineering). The moisture content at which a soil changes from a solid to a plastic state.

Precipitation-effectiveness $(P-E)$ index. The sum of the 12 monthly quotients of precipitation divided by the evaporation during the 12 months.

Profile, soil. A vertical section of the soil through all its horizons and extending into the parent material. See Horizon, soil.

Quartz. Brilliant, crystalline mineral, silicon dioxide, sio, occurring in abundance, most often in a colorless, transparent form, but also sometimes as variously colored semi-precious stones.

Quartzite. Massive hard, light-colored rock with a flinty sheen; it is a metamorphosed sandstone.

Range (or rangeland). Land that, for the most part, produces native plants suitable for grazing by livestock; includes land on which there are some forest trees.

Range condition. The state of health or productivity of both soil and forage in a given range, in terms of what it could or should be under normal climate and the best practical management. Condition classes generally recognized are--excellent, good, fair, and good. The classification is based on the percentage of original, or climax, vegetation on the site, as compared to what ought to grow on it if management were good.

Range plant cover. All the herbaceous and shrubby plants on a range that livestock can reach, regardless of whether these plants constitute forage.

Range site. An area of range where climate, soil and topography are sufficiently uniform to produce a distinct kind of climax vegetation.

Range survey. A systematic, comprehensive inventory and analys is of the range resources and the related problems of management, in a range area, and development of plans for its management.

Range type. An area of range differentiated from other range areas primarily by its kind of plant cover, such as grass, browse, or conifer.

Reaction, soil. The degree of acidity or alkalinity of a soil expressed in pli values. A soil that tests to pH 7.0 is precisely neutral in reaction, because it is neither acid or alkaline. In words the degrees of acidity or alkalinity are expressed thus: 
Extremely acid

Very strongly acid

Strongly acid

Medium acid

Slightly acid
$\mathrm{pH}$

Below 4.5 ueutral

4.5 to 5.0 Mildiy alkaline

5.1 to 5.5 Moderately alkaline

5.6 to 6.0 strongly alkaline

6.1 to 6.5 Very strongly alkaline
6. ${ }^{\mathrm{pH}}$

7.3

7.4 to 7.8

7.9 to 8.4

8.5 to 9.0

above pH! 9.0

Rhyolite. A type of volcanic rock containing much silica and resembling granite in composition but having a texture that shows flow.

Ridge terrace. A long, low ridge of earth that has gently sloping sides and a shallow channel along the upper side; controls erosion by diverting surface runoff across the slope instead of allowing it to flow uninterrupted down the slope. Compare with Bench terrace.

Rolling. Having moderately steep, complex slopes; intermediate between undulating and hilly.

Root zone. The part of the soil that is penetrated, or can be penetrated by plant roots.

Sand. Individual rock or mineral fragments in soils having diameters ranging from 0.05 to 2.0 millimeters. Most sand grains consist of quartz, but they may be of any mineral composition. The textural class name of any soil that contains 85 percent or more sand and not more than 10 percent clay.

Sandy soils. A broad term for soils of the sand and loamy sand classes; soil material with more than 70 percent and less than 15 percent clay.

Sedimentary rock. A rock composed of particles deposited from suspension in water. The chief sedimentary rocks are conglomerate from gravel, sands one from sand; shale from clay; and limestone from soft masses of calcium carbonate. There are many intermediate types. Some wind deposited sands have been consolidated into sandstone.

Seni-arid climate. A climate intermediate hetween that of a true desert and a subhumid area.

Series, soil. A group of soils developed from a particular type of parent material and having genetic horizons that, except for texture of the surface soil, are similar in differentiating characteristics and in arrangement in the profile.

Sesquioxides. Oxides having trivalent cations, as iron or aluminum oxides.

Shale. A sedimentary rock formed by the hardening of clay deposits.

Sheet erosion. The removal of a fairly uniform layer of soil or material from the land surface by the action of rainfall and runoff water.

Silica. An important soil constituent composed of silicon and oxygen. The essential materjal in the mineral called quartz.

Silica-sesquioxide ratio. The ratio of the number of molecules of silica to the number of molecules of alumina plus iron oxide in a soil or the ciay fraction of a soil. The more highly weathered materiais in warm-temperate humid regions and especiainy those in the tropics, generally have low ratios. The clay in soils with low ratios normally are less active, physically and chemically than tincse with high ratios. 
Silt. Individual mineral particles in a soil that range in diameter from the upper limit of clay $(0.002 \mathrm{millimeters)}$ to the lower limit of very fine sand $(0.05$ millimeters). Soil of the silt textural class is 80 percent or more silt and less than 12 percent clay.

soil map. A map designed to show the distribution of soil mapping units in relation to the prominent physical and cultural features of the earth's surface.

Soil series. Soils qroup having soil horizons similar in differentiating characteristics and arangement in the soil profile, except for the texture of the surface soil, and developed from a particular type of parent material. (The names of the soil series in this report is tentative.)

Soil separates. Mineral particles, less than 2 millimeters in equivalent diameter and ranging between specified size limits. The names and sizes of separates recognized in the United States are as follows:

Very coarse sand $(2.0$ to 1.0 millimeter $)$; coarse sand $(1.0$ to 0.5 millimeter); medium sand $(0.5$ to 1.25 millimeter); fine sand $(0.25$ to 0.10 millimeter) very fine sand $(0.10$ to 0.05 to 0.002 millimeter): and clay (less than 0.002 millimeter). The separates recognized by the International Society of Soil Science are as follows: I $(2.0$ to 0.2 millimeters): II $(0.2$ to 0.02 millimeters $)$; III $(0.02$ to 0.002 millimeters); IV (less than 0.002 millimeter).

Soil survey. A systematic examination, description, classification, and mapping of soils in an area. Soil surveys are classified accordingly to intensity of field examination as exploratory, reconnaissance, or detailed.

Solum ( $p$ i. sola). The upper part of a soil profile, above that parent material, in which the processes of soil formation are active. The solum in mature soil includes the $A$ and $B$ horizons. Generally, the characteristics of the material in these horizons are unlike those of the underlying parent material. The living roots and other plant and animal life characteristic of the soll are largeiy confined to the solum.

Stones. Rock fragments greater than 10 inches in diameter if rounded. and greater than 15 inches along the longer axis if flat.

Stony. Used to describe soils that contain stones in numbers that interfere with or prevent tillage.

Stratified. Composed of, or arranged in, strata, or layers, such as stratified alluvium. The term is confined to geological material. Layers in soil that result from the processes of soil formation are called horizons; those inherited from the parent material are called strata.

Structure, soil. The arrangement of primary soil particles into compound particles or clusters that are separate from adjoining aggregates and have properties unlike those of an equal mass of unaggregated primary soil particles. The principal forms of soil structure are platy, (laminated), prismatic, (vertical axis of 
aggregates longer than horizontal), columnar, (prisms with rounded tops), blocky, (angular or subangular), and granular. Structureless soils are (1) single grain (each arain by itseif as in dune sand) or (2) massive (the particles adhering together without any regular cleavage, as in many claypans and hardpans).

Subsoil. Technically, the $B$ horizon; roughly, the part of the profile below plow depth.

Substratum. Any layer lying beneath the solum, or true soil; the $\mathrm{C}$ or D horizon.

Surface layer. A term used in nontechnical soil descriptions for one or more layers above the subsoil. Includes $A$ horizon and part of $B$ horizon; has no depth limit.

Surface soil. The soil ordinarily moved in tillage, or its equivalent in uncultivated soil, about 5 to 8 inches in thickness. The plowed layer.

Terrace. An embankment, or ridge, constructed-across sloping soils a the contour or at a slight angle to the contour. The terrace intercepts surplus runoff so that it may soak into the soil or flow slowly to a prepared outlet without harm. Terraces intended mainly for drainage have a deep channel that is maintained in permanent soil. See also broadbase terrace, narrowbase terrace, bench terrace.

Terrace (geological). An old alluvial plain, ordinarily flat or undulating bordering a river, lake, or the sea. Stream terraces are frequently called second bottom, as contrasted to flood plains, and are seldom subject to overflow. Marine terraces were deposited by the sea and are generally wide.

Topsoil. A presumed fertile soil or soil material, ordinarily rich in organic matter used to topdress roadbanks, lawns, and garders.

Trace elements. The chemical elements found in soils in extremely small amounts, yet which are essential to plant growth. Some of the trace elements are zinc, cobalt, manganese, and copper. Synoynm: Minor elements.

Tuff. Porous rock, usualiy stratified, formed by consolidation of volcanic ashes, dust, etc.

Type, soil. A subdivision of the soil series that is made on the basis of differences in the texture of the surface layer.

Typic Durorthids. Typic means typical. Dur-orthids mean durable and orthophoric are combined into the word Durorthids. The duripan has an upper boundary within 40 inches of the surface.

value (color). One of three variables of color. Value increases as the relative intensity of reflected light increases. See Munsell notation. 